\title{
Isolation of New Steroids of Kala Dhaman Grass (Cenchrus setigerus) and Evaluation of Their Bioactivity
}

\author{
Premlata Singariya $^{1 *}$, Padma Kumar ${ }^{1}$ and Krishan Kumar Mourya ${ }^{2}$ \\ ${ }^{1}$ Laboratory of Tissue Culture and Secondary Metabolites; Department of Botany; University of Rajasthan; Jaipur. \\ ${ }^{2}$ Veterinary Hospital; Pahari (Bharatpur); Rajasthan - India
}

\begin{abstract}
The present study was carried out to determine the possible bioactive components (steroids) of Cenchrus setigerus using GC-MS analysis and in vivo estimation of metabolites (total soluble sugar, soluble protein, proline and total phenolics), photosynthetic pigments (chlorophyll-a, chlorophyll-b and carotenoids) of seedlings and antimicrobial activity of extracts in various polar solvents from the leaves of C. setigerus. Antimicrobial activity was evaluated against three Gram-negative bacteria, including Proteusmirabilis, Klebsiella pneumonia and Agrobacterium tumefaciens andone fungus Aspergillus niger using 'disc diffusion' method, followed by the determination of minimum inhibitory concentrations (MIC) by broth dilution method. Results revealed the presence of some steroids in the isopropyl alcohol extract of $\mathrm{C}$. setigerus:which are (22E)-stigmasta-4,22-dien-3-one(4.93\%), 84 -sitosterol-3one (stigmast-4-en-3-one) (4.31\%), fagarsterol (lupeol) (1.25\%) and ethyl iso-allocholate (0.32\%). Total soluble sugars and chlorophyll-a were also recorded to be highest. The highest activity was exhibited by the isopropyl alcohol and ethyl acetate extract against $\mathrm{P}$. mirabilis.
\end{abstract}

Key words: Cenchrus grass, photosynthetic pigments, total soluble sugar, proline; Antibacterial activity, MIC, $\mathrm{MBC} / \mathrm{MFC}$

\section{INTRODUCTION}

The chemical analysis of isopropyl alcohol extract of Cenchrus setigerus showed a mixture of longchain hydrocarbons, carboxyl esters, alcohols, acids, alkaloids, steroids, amino and nitro compound etc. Phytochemical screening using the pharmacognostic methods revealed the presence of flavonoids, steroids and alkaloids. Taking into consideration of the medicinal importance of this plant, the isopropyl alcohol extract of $C$. setigerus was analyzed for the first time using GC-MS following the method of Hema et al. 2010. This work will help to identify the compounds (steroids) of therapeutic value. GC-MS is the best technique to identify the bioactive constituents of long chain hydrocarbons, alcohols, acids, ester, alkaloids, steroids, amino and nitro compounds, etc. (Amakrishnan 2011).

$\mathrm{C}_{4}$ grasses have gained attention in various field of research, as they are best suited to the present environmental conditions. They are more competitive under the conditions of high temperature, solar radiation and low moisture (Agrawal 2007). C. setigerus is more efficient in capturing carbon dioxide and utilizing nitrogen from the atmosphere and recycle $\mathrm{N}$ in the soil (Bessman 1956; Singariya 2009). The grass has excellent soil binding capacity, which helps to conserve the soil in desert areas (Sinha et al.

*Author for correspondence: premlatasingariya@gmail.com 
1996). However, C. setigerus is most suitable and highly nutritive grass for desert environmental conditions; still no antimicrobial studies have so far been done for this grass.

Carotenoids act as accessory light-harvesting pigments as well as for the protection of chloroplasts from light mediated stress (Siefermann-Harms 1987). Proline has been reported to protect protein structure and membrane from damage and to reduce the enzyme denaturation (Rajendra kumar et al.1994). Alternatively, proline accumulation has also been proposed for nitrogen storage (Larcher 1995).

Antimicrobial resistance developing in pathogens towards antibodies has leads to treatment failure and necessitates the search for new antimicrobials (Otimentin et al. 2008). Plants derived compounds contribute a lot in fight against pathogens (Vyvyan 2002). Various plant extracts can serve both as potential antimicrobial crude drugs as well as a source of new anti-infective agents (Rios, 2005).

The aim of the present study was to investigate the possible bioactive components of $C$. setigerus using GC-MS analysis and in vivo estimation of metabolites (total soluble sugar, soluble protein, proline and total phenolics), photosynthetic pigments (chlorophyll-a, chlorophyll-b and carotenoids) of seedlings and antimicrobial activity of the extracts in various polar solvents from the leaves of $C$. setigerus against important pathogenic microbes.

\section{MATERIALS AND METHODS}

\section{Experimental design: \\ Identification of Components}

Analysis of extracts was performed using a GCMS (Model; QP 2010 series, Shimadzu, Tokyo, Japan) equipped with a VF-5 ms fused silica capillary column of $60 \mathrm{~m}$ length, $0.25 \mathrm{~mm}$ dia. and $0.25 \mathrm{~mm}$ film thickness; injection mode: split; flow control mode: linear velocity; pressure: 173.3 $\mathrm{kPa}$; linear velocity: $28.9 \mathrm{~cm} / \mathrm{sec}$; purge flow: 3.0 $\mathrm{mL} / \mathrm{min}$; split ratio: 10.0. For GC-MS detection [GC-2010], an electron ionization system with ionization energy of $70 \mathrm{eV}$ was used. Helium gas (99.99\%) was used as a carrier gas at a constant flow rate- total flow: $16.3 \mathrm{~mL} / \mathrm{min}$. and column flow: $1.21 \mathrm{~mL} / \mathrm{min}$. injector and mass transfer line temperature were set at 200 and $240^{\circ} \mathrm{C}$, respectively. The oven temperature was programmed (column oven temp.: $100^{\circ} \mathrm{C}$ and injection temp.: $270^{\circ} \mathrm{C}$ ) from 70 to $220^{\circ} \mathrm{C}$ at $10^{\circ} \mathrm{C} / \mathrm{min}$, held isothermal for $1 \mathrm{~min}$ and finally raised to $300^{\circ} \mathrm{C}$ at the rate of $10^{\circ} \mathrm{C} / \mathrm{min}$. A $2.0 \mathrm{~m} \mathrm{~L}$ of respective diluted samples were manually injected in the split less mode, with split ratio of 1:40 and with mass scan of 50-600 amu. Total running time of GC-MS was 48 min.

The relative amount of each component was calculated by comparing its average peak area to the total areas, software adopted to handle mass spectra and chromatograms was a Turbo mass. The relative percentage of the each extract constituents was expressed as percentage with peak area normalization. Interpretation on mass spectrum of GC-MS was done using the database of National Institute of Standard Technology (NIST) having more than 62,000 patterns. The mass spectrum of the unknown component was compared with the spectrum of the known components stored in the NIST library. The name, molecular weight and structure of the components of the test materials were ascertained (Muthulakshmi et al. 2012).

\section{Photosynthetic pigments and metabolite: \\ In-vivo studies}

For in vivo studies, seeds of $C$. setigerus (CAZRI76) were grown in 12" earthen-ware pots. Pots were filled with $8 \mathrm{~kg}$ of a mixture of garden soil and goat manure in the ratio of 3:1 and were watered every day. After two weeks of sowing, thinning was done and 3-4 plants of uniform size were selected in each pot. Leaf samples were collected for the biochemical analysis (Singariya et al. 2009).

\section{Preparationofextract}

All the operations for preparing the extracts were performed at $4^{\circ} \mathrm{C}$. Plant material (in vivo-leaves) were homogenized using appropriate buffer in prechilled pestle mortar and centrifuged at 10,000 $\mathrm{rpm}$ for $20 \mathrm{~min}$. The supernatant collected was used for all the metabolites estimation.

\section{Estimation of soluble protein}

Soluble proteins were estimated by the method of Bradford (1976). This involved the binding of Coomassie Brilliant Blue G-250 (CBB-G-250) to the proteins.

\section{Estimation of proline}

Bates et al. (1973) method was used for estimating the proline content. The extracted proline was 
made to react with ninhydrin in acidic conditions to form the chromophore (red colour), which was read at $520 \mathrm{~nm}$.

\section{Estimation of total soluble sugars}

Total soluble sugars were estimated in accordance with Mc-Ready et al. (1950) method.

\section{Total Phenolics}

The phenols in the extracts were determined according to Folin-Ciocalteu procedure (Singleton and Rossi 1995).

\section{Photosynthetic pigments}

The leaves $(500 \mathrm{mg})$ were homogenized in $5.0 \mathrm{~mL}$ of $80 \%$ acetone, centrifuged for $20 \mathrm{~min}$ at 10,000 $\mathrm{rpm}$ and the supernatant was used for the estimation of photosynthetic pigments. The absorbance was recorded at 663, 645 and $470 \mathrm{~nm}$ against $80 \%$ acetone as blank. Arnon's (1949) method was used for the calculation of chlorophyll content.

\section{Antimicrobial Activity Plant material}

The seeds of $C$. setigerus (variety: CAZRI-358) were collected in the month of August 2009 from the CAZRI, Jodhpur, Rajasthan. The collected plant materials were transferred immediately to the laboratory, cleaned with water. The selected plant parts were separately shade dried until constant weight. Shade dried parts were powdered with the help of grinder (Hussain et al. 2010).

\section{Preparation of extracts}

Crude extracts of the seeds of $C$. setigerus were prepared with a series of non- polar to polar solvents by hot extraction method (Harborne 1984) in Soxhlet assembly. Different extracts were then screened for their antimicrobial activity by 'Disc Diffusion Assay' (Singariya et al. 2012a) against a few medically important bacteria and fungi. The fraction showing best activity was then used for determining the MIC by broth dilution method (Singariya et al. 2011b) and minimum bactericidal/fungicidal concentration (MBC/MFC).

\section{Micro-organisms}

The organisms used in the study were three Gramnegative bacteria viz., Proteus mirabilis (MTCC3310), Klebsiella pneumoniae (MTCC-4030), Agrobacterium tumefaciens (MTCC-431) and one fungus, Aspergillus niger (MTCC-282). Selected microorganisms were procured from IMTECH, Chandigarh, India.

\section{Maintenance of test pathogens culture and Disc diffusion assay}

The bacterial strains were grown and maintained on Nutrient Agar (NA) medium, while fungus was maintained on Sabouraud Dextrose Agar (SDA) medium. Disc diffusion assay (DDA) was performed for screening by the standard method (Singariya et al. 2011c). NA and SDA plates were seeded with the bacterial and fungal inoculum, respectively using the inoculum size of $1 \times 10^{8}$ $\mathrm{CFU} / \mathrm{mL}$ for the bacteria and $1 \times 10^{7} \mathrm{cell} / \mathrm{mL}$ for the fungus. Sterile filters paper discs (Whatman no. $1,5 \mathrm{~mm}$ in diameter) were impregnated with $100 \mu \mathrm{L}$ of each of the extract $(10 \mathrm{mg} / \mathrm{mL})$ to give a final concentration of $1 \mathrm{mg} /$ disc and dried in vacuum so as to remove the residual solvent. Extract discs were then placed on the seeded agar plates. Each extract was tested in triplicate along with gentamycin $(10 \mathrm{mcg} / \mathrm{disc})$ and ketoconazole $(10 \mathrm{mcg} / \mathrm{disc})$ as the standard for bacteria and fungi, respectively. The plates were kept at $4{ }^{\circ} \mathrm{C}$ for $1 \mathrm{~h}$ for the diffusion of extract, thereafter were incubated at $37^{\circ} \mathrm{C}$ for bacteria $(24 \mathrm{~h})$ and $27^{\circ} \mathrm{C}$ for fungi $(48 \mathrm{~h})$. The inhibition zones were measured and compared with the standard reference antibiotics. Activity index for each extract was calculated by the formula.

$$
\text { Activity index }(\mathrm{AI})=\frac{\text { Inhibition Zone of the sample }}{\text { Inhibition Zone of the standard }}
$$

\section{Serial dilution method}

The MIC was determined as the least extract concentration, which inhibited the growth of the test organisms (Jain and Sharma 2009; Singariya et al. 2012d). The bacterial and fungal suspensions were used as negative control, while broth containing standard drug was used as positive control.

\section{Determination of Minimum bactericidal/ fungicidal concentration (MBC/MFC)}

Equal volume of the various concentration of each extract and nutrient broth were mixed in microtubes to make up $0.5 \mathrm{~mL}$ of the solution; $0.5 \mathrm{~mL}$ of McFarland standard of the organism suspension was added to each tube (Bhattacharya et al. 2009). The tubes were incubated aerobically and MBC was determined by sub-culturing and further 
incubated for $24 \mathrm{~h}$. The highest dilution that yielded no single bacterial colony was taken as the MBC (Singariya et al. 2012b).

\section{Total activity (TA) determination}

Total activity is the volume at which the test extract can be diluted with the ability to kill the microorganisms. It is calculated by dividing the amount of extract from $1.0 \mathrm{~g}$ plant material by the MIC of the same extract, or the compound isolated and expressed in $\mathrm{mL} / \mathrm{g}$ (Singariya et al. 2012c).

$$
\text { Total Activity }=\text { Extract per gram dried plant part }
$$

\section{RESULTS AND DISCUSSION}

\section{GC-MS analysis}

GC-MS results revealed following steroids (22E)stigmasta-4,22-dien-3-one $(4.93 \%$ retention time$37.32 \mathrm{~min}$ and area-197485) (Fig. 1), 84 -sitosterol3 -one (stigmast-4-en-3-one) $\quad(4.31 \%$ retention time-38.795 $\mathrm{min}$ and area-1725255) (Fig. 2), fagarsterol (lupeol) (1.25\% retention time-36.943 min. and area-500335) (Fig. 3), which has been used as anti-cancer drug and ethyl iso-allocholate (0.17\% retention time-39.707 min and area-66937) (Fig. 4), which has antimicrobial, diuretic and antiinflammatory activity. However, till-date there was no report on the presence of steroids from $C$. setigerus.

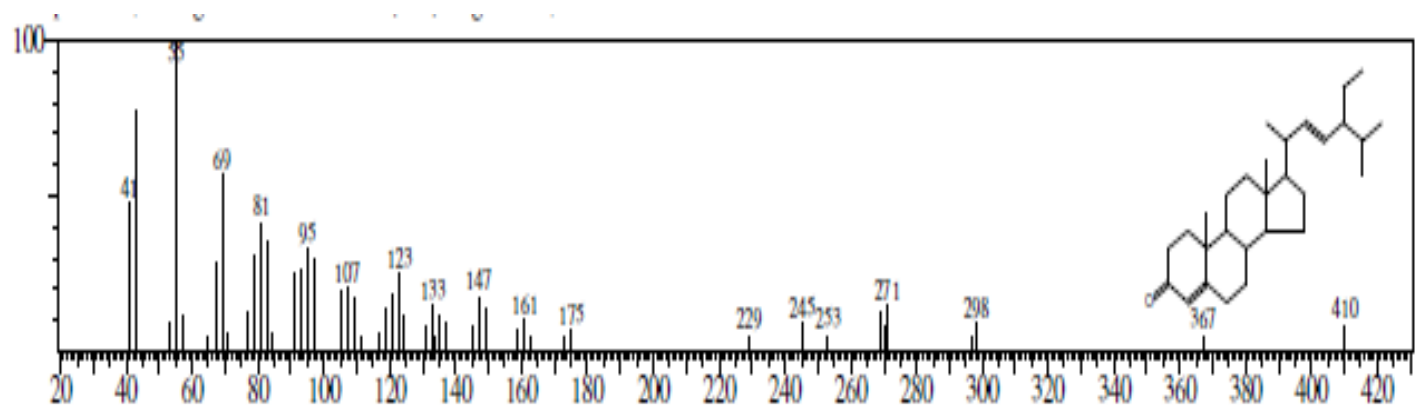

Figure 1 - Mass Spectrum of 4,22-Stigmastadiene-3-one (RT- $37.325 \mathrm{~min}$.).

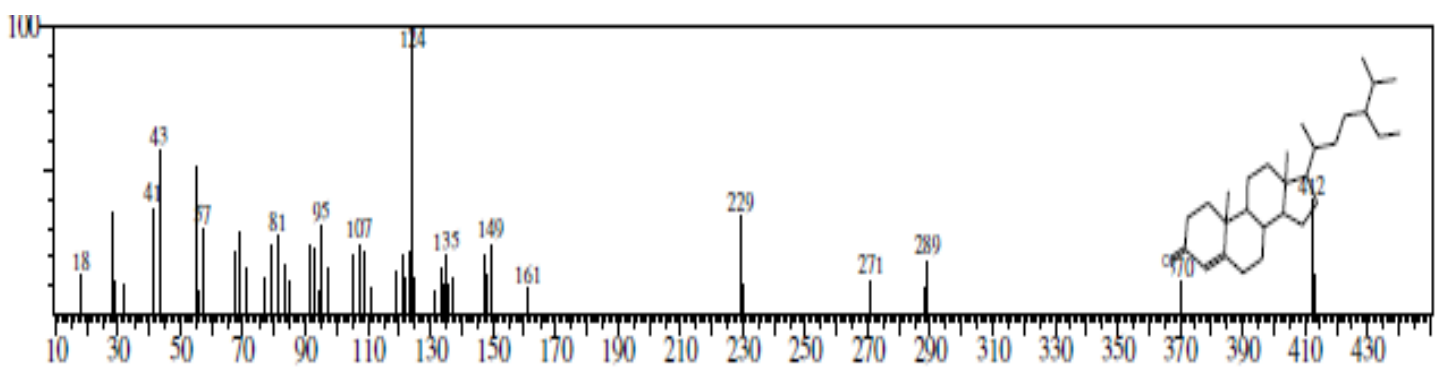

Figure 2 - Mass Spectrum of Delta.4-Sitosterol-3-one (RT - 38.795 min.)

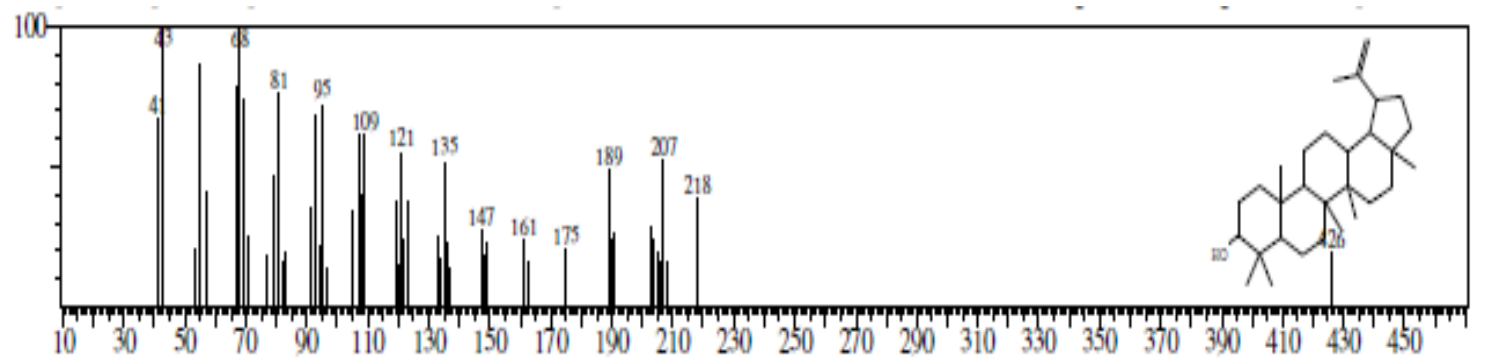

Figure 3 - Mass Spectrum of Fagarsterol (Lupeol) (RT- 36.943 min.). 


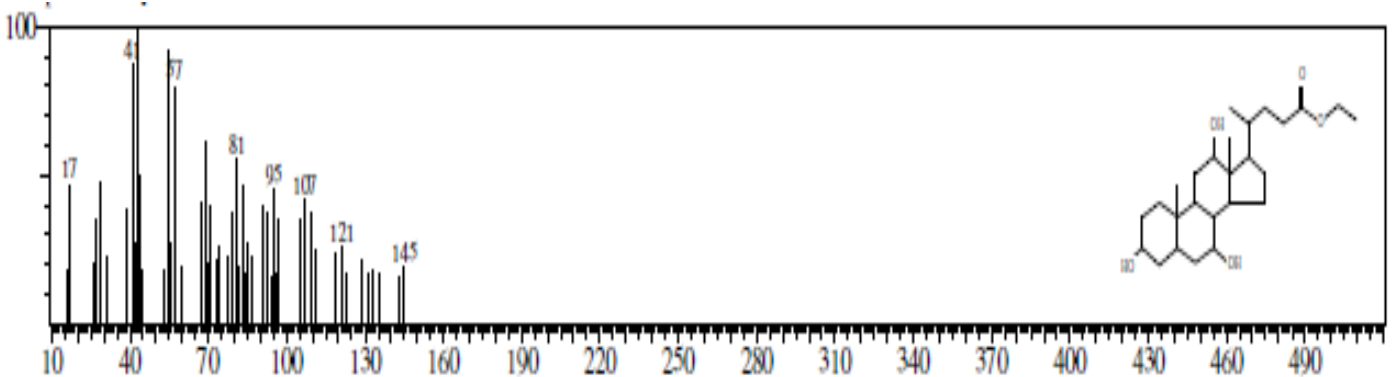

Figure 4 - Mass Spectrum of Ethyl iso-allocholate (RT- 39.707 min.).

\section{Photosynthetic pigments and metabolite Metabolites}

In vivo study of $C$. setigerus showed highest total soluble sugars $(20.43 \pm 0.143 \mathrm{mg} / \mathrm{g} \mathrm{F}$. wt.), followed by total phenolics $(12.125 \pm 0.145 \mathrm{mg} / \mathrm{g}$ F. wt.) among all the metabolites and proline was recorded as $0.089 \pm 0.013 \mathrm{~m} \mathrm{~mol} / \mathrm{g} \mathrm{F}$. wt. (Table $1)$.

Table 1 - Different metabolites of Cenchrus setigerus.

\begin{tabular}{|c|c|c|}
\hline S. No. & Metabolites & $\begin{array}{l}\text { Cenchrus setigerus (In- } \\
\text { vivo) }\end{array}$ \\
\hline 1 & ה & $11.42 \pm 0.143 \mathrm{mg} / \mathrm{g}$ F. wt. \\
\hline 2 & Total & $20.43 \pm 0.143 \mathrm{mg} / \mathrm{g}$ F. wt. \\
\hline 3 & Proline & $\begin{array}{l}0.089 \pm 0.013^{*} \mathrm{~m} \mathrm{~mol} / \mathrm{g} \\
\text { F. wt. }\end{array}$ \\
\hline 4 & Total Phenolics & $\begin{array}{l}12.125 \pm 0.145 \mathrm{mg} / \mathrm{g} \\
\text { F. wt. }\end{array}$ \\
\hline
\end{tabular}

*SD value $\mathrm{X} 10^{-3}$

\section{Photosynthetic Pigments}

Table 2 shows the results of photosynthetic pigments chlorophyll a, chlorophyll $b$ and carotenoids (mg/g F. wt.). Chlorophyll a was highest $(0.829 \pm 0.012)$, followed by chlorophyll $\mathrm{b}$ $(0.393 \pm 0.009)$.

Table 2 - Photosynthetic Pigments of Cenchrus setigerus.

\begin{tabular}{cll}
\hline S.No. & Pigments & Cenchrus setigerus (In-vivo) \\
\hline $\mathbf{1}$ & Chlorophyll a & $0.829 \pm 0.012 \mathrm{mg} / \mathrm{g} \mathrm{F}$. wt. \\
$\mathbf{2}$ & Chlorophyll b & $0.393 \pm 0.009 \mathrm{mg} / \mathrm{g} \mathrm{F}$. wt. \\
$\mathbf{3}$ & Carotenoids & $0.159 \pm 0.008 \mathrm{mg} / \mathrm{g} \mathrm{F}$. wt. \\
\hline *SD value X10
\end{tabular}

\section{Antimicrobial Activity \\ Zone of inhibition (ZOI) and Activity Index (AI)}

Table 3 shows the results of the antimicrobial activity (assessed in terms of ZOI and $\mathrm{AI}$ ) of the seed extracts in different polar solvents, tested against selected microorganisms. Most susceptible organism in the investigation was A. tumefaciens (Singariya et al. 2012e) against which most of the plant extracts showed inhibition zone but, according the zone of inhibition P. mirabilis was the most susceptible organism. Maximum antimicrobial activities were observed by glacial acetic acid (GAA) and ethyl acetate extracts in $C$. setigerus.

Table 3 - Zone of Inhibition (mm)* and Activity index of seed extracts of Cenchrus setigerus.

\begin{tabular}{|c|c|c|c|c|c|c|c|c|}
\hline \multirow{3}{*}{ Polar Solvents } & \multicolumn{8}{|c|}{ Bio-activity of seed extracts of Cenchrus setigerus against pathogens } \\
\hline & \multicolumn{2}{|c|}{ Proteus mirabilis } & \multicolumn{2}{|c|}{ Klebsiella pneumoniae } & \multicolumn{4}{|c|}{ Agrobacterium tumefaciens Aspergillus niger } \\
\hline & ZOI & AI & ZOI & AI & ZOI & AI & $\mathrm{ZOI}$ & AI \\
\hline Water & & & & & & & - & - \\
\hline Acetic acid & $38.50 \pm 0.64$ & 3.208 & $34.83 \pm 0.24$ & 1.742 & $25.5 \pm 0.64$ & 1.159 & - & - \\
\hline Ethanol & $7.83 \pm 0.23$ & 0.559 & $10.17 \pm 0.27$ & 0.509 & $9.33 \pm 0.24$ & 0.467 & - & - \\
\hline Acetone & $7.33 \pm 0.26$ & 0.814 & $8.17 \pm 0.25$ & 0.409 & $10.33 \pm 0.24$ & 0.470 & - & - \\
\hline Ethyl acetate & $15.83 \pm 0.27$ & 1.131 & $11.33 \pm 0.23$ & 0.567 & $10.17 \pm 0.24$ & 0.636 & - & - \\
\hline Chloroform & - & - & $8.17 \pm 0.24$ & 0.409 & $9.67 \pm 0.27$ & 0.484 & - & - \\
\hline Iso propyl alcohol & $16.50 \pm 0.64$ & 1.833 & $11.67 \pm 0.24$ & 0.584 & $10.5 \pm 0.64$ & 0.700 & - & - \\
\hline Benzene & - & - & $8.5 \pm 0.64$ & 0.425 & $9.5 \pm 0.64$ & 0.792 & - & - \\
\hline Toluene & - & - & - & - & - & - & - & - \\
\hline Petrolium ether & - & - & - & - & - & - & - & - \\
\hline Hexane & - & - & - & - & - & - & - & - \\
\hline
\end{tabular}

All values are mean $\pm \mathrm{SD}, \mathrm{n}=3, \mathrm{ZOI}=$ Zone of Inhibition $(\mathrm{mm} \pm \mathrm{S} . \mathrm{D}),. \mathrm{AI}=$ Activity index, ${ }^{*}=$ millimeter. 
Isopropyl alcohol extract showed highest activity after GAA extract (ZOI-16.50 $\pm 0.64 \mathrm{~mm}$, AI1.833), (ZOI- $11.67 \pm 0.24 \mathrm{~mm}$, AI- 0.584) and (ZOI- $10.50 \pm 0.64 \mathrm{~mm}$, AI- 0.700) against $P$. mirabilis, $K$. pneumoniae and A. tumefaciens respectively.

\section{MIC and MBC/MFC}

As shown in the Table 4, the range of MIC and

MBC/MFC of the extracts was $0.117-15 \mathrm{mg} / \mathrm{mL}$. The lowest MIC value $0.117 \mathrm{mg} / \mathrm{mL}$ was recorded for GAA extracts against $P$. mirabilis and $K$. pneumonia, followed by $0.234 \mathrm{mg} / \mathrm{mL}$ against $A$. tumefaciens by the same, indicating significant antimicrobial potential of test extracts. The MIC and $\mathrm{MBC} / \mathrm{MFC}$ values were equal for the GAA extracts showing the bactericidal properties of test extracts.

\section{Total activity}

Total activity indicated the volume at which extract could be diluted without losing the ability to kill the microorganisms. Most of the extracts showed high values of TA against $P$. mirabilis, $K$. pneumoniae and A. tumefaciens, which proved the potential to inhibit the growth of the test microorganisms, even at low concentration. Maximum TA values calculated were $378.63 \mathrm{~mL}$ against $P$. mirabilis and $K$. pneumonia, followed by $189.32 \mathrm{~mL}$ against $A$. tumefaciens. The test pathogens were more sensitive to iso - propyl alcohol, ethyl acetate and acetone extracts after GAA extracts than to the rest of the extracts (Table $5)$.

Table 4 - MIC and MBC/MFC of seed extracts of $C$. setigerus in different polar solvents.

\begin{tabular}{ccccccccc}
\hline Polar & \multicolumn{6}{c}{ Bio-activity of seed extracts of Cenchrus setigerus against pathogens } \\
Solvents & \multicolumn{2}{c}{$P$ mirabilis } & \multicolumn{2}{c}{ K. pneumoniae } & \multicolumn{2}{c}{ A. tumefaciens } & \multicolumn{2}{c}{ A. niger } \\
& MIC & MBC & MIC & MBC & MIC & MBC & MIC & MFC \\
\hline Water & - & - & - & - & - & - & - & - \\
Acetic acid & 0.117 & 0.117 & 0.117 & 0.117 & 0.234 & 0.468 & - & - \\
Ethanol & 7.5 & 15 & 3.75 & 7.5 & 3.75 & 3.75 & - & - \\
Acetone & 7.5 & 15 & 7.5 & 15 & 3.75 & 7.5 & - & - \\
Ethyl acetate & 1.875 & 1.875 & 3.75 & 7.5 & 7.5 & 15 & - & - \\
Chloroform & - & - & 7.5 & 7.5 & 7.5 & 7.5 & - & - \\
Iso propyl alcohol & 1.875 & 1.875 & 3.75 & 7.5 & 1.875 & 3.75 & - & - \\
Benzene & - & - & 7.5 & 7.5 & 1.875 & 1.875 & - & - \\
Toluene & - & - & - & - & - & - & - & - \\
Petrolium ether & - & - & - & - & - & - & - & - \\
Hexane & - & - & - & - & - & - & - & - \\
\hline
\end{tabular}

MIC-Minimum inhibitory concentration (mg/ml), MBC-Minimum bactericidalconcentration (mg/ml), MFC-Minimum fungicidal concentration $(\mathrm{mg} / \mathrm{mL})$.

Table 5 - Total activity of seed extracts of Cenchrus setigerus in different polar solvents.

\begin{tabular}{ccccc}
\hline \multicolumn{2}{c}{ Polar } & \multicolumn{2}{c}{ Total activity of seed extracts of Cenchrus setigerus against pathogens } \\
Solvents & P. mirabilis & K. pneumoniae & A. tumefaciens & A. niger \\
\hline Water & - & - & - & - \\
Glacial Acetic acid & 378.63 & 378.63 & 189.32 & - \\
Ethanol & 4.61 & 9.23 & 9.23 & - \\
Acetone & 3.45 & 3.45 & 6.91 & - \\
Ethyl acetate & 20.59 & 10.29 & 5.15 & - \\
Chloroform & - & 5.19 & 5.19 & - \\
Isopropyl alcohol & 18.45 & 9.23 & 18.45 & - \\
Benzene & - & 1.61 & 6.45 & - \\
Toluene & - & - & - & - \\
Petrolium ether & - & - & - & - \\
Hexane & - & - & - & \\
\hline
\end{tabular}

\section{Quantitative phyto-chemical estimation}

The phyto-chemical estimation for the seeds of $C$. setigerus were carried out according to Farnsworth (1966) wherein the consistency was sticky in the high polar solvent extracts whereas the low polar solvent extracts were non-sticky, which was same as described by Singariya et al. (2011a) but hexane, benzene and toluene extracts were sticky and water extract was non-sticky. The yield $(\mathrm{mg} / 10 \mathrm{gm} \pm$ S.D.) of the extracts was also analyzed and highest yield for $C$. setigerus was observed in GAA extracts (Table 6). 
Table 6 - Phyto-chemical estimation of seed extract of $C$. setigerus in different polar solvents.

\begin{tabular}{cccc}
\hline Polar & \multicolumn{2}{c}{ Primary Phyto-chemical estimation of seed extracts of $\boldsymbol{C}$. setigerus } \\
\cline { 2 - 3 } & Total Yield (mg/10 gm \pm S.D.) & Color & Consistency \\
\hline Water & $202 \pm 11.37$ & Dark brown & Nonsticky \\
Glacial Acetic acid & $443 \pm 17.69$ & Brick red & Sticky \\
Ethanol & $346 \pm 13.46$ & Yellow & Sticky \\
Acetone & $259 \pm 14.45$ & Dark yellow & Nonsticky \\
Ethyl acetate & $386 \pm 14.54$ & Green & Nonsticky \\
Chloroform & $389 \pm 8.95$ & Yellow & Sticky \\
Isoppopyl alcohol & $346 \pm 10.13$ & Cream color & Nonsticky \\
Benzene & $121 \pm 15.63$ & Yellow & Sticky \\
Toluene & $174 \pm 10.69$ & Light brown & Sticky \\
Petrolium ether & $260 \pm 17.93$ & Light cream & Nonsticky \\
Hexane & $128 \pm 13.41$ & Brick red & Sticky \\
\hline
\end{tabular}

The presence of various bioactive compounds justifies the use of this plant for various ailments by traditional practitioners. However, the isolation of individual phytochemical constituent and subjecting it to the biological activity would definitely give fruitful results. Isopropyl alcohol extract of the $C$. setigerus showed some bioactive compounds, namely stigmast-4-en-3-one, fagarsterol (lupeol) and ethyl iso-allocholate. These compounds have antimicrobial, diuretic, anti-cancers and anti-inflammatory activity. In the light of the fact that microorganism are becoming resistant against the existing drugs, present study if explored further can be of great use by the pharmaceutical industries for preparing the plant based antimicrobials drugs are concerned. Most susceptible organism in the investigation was $A$. tumefaciens and $P$. mirabilis. Cenchrus grass easily grows in harsh climatic conditions or xeric conditions and requires less care; hence its use as raw material for preparing the drugs could be economical.

\section{ACKNOWLEDGEMENT}

Authors are thankful to the UGC for providing the funds under Dr. D. S. Kothari Post-doctoral fellowship scheme.

\section{REFERENCES}

Agrawal P. Ecophysiological and Biochemical studies related to drought adaptation in grasses of Indian Desert. Ph.D. Thesis. J. N. Vyas University, 2007.

Amakrishnan N. GC-MS Analysis of Rumexvesicarius L. Int J Drug Development \& Res. 2011; 3(2): 272279.
Arnon DI. Copper enzymes in isolated chloroplast: polyphenol oxidase in Beta vulgaris. Plant Physiol. 1949; 24: 1-5.

Bates LR, Waldern RP, Teare ID. A rapid determination of free proline for water stress studies. Plant Soil. 1973; 39: 205-207.

Bessman SP. Ammonia Metabolism in Animals: Symposium on Inorganic Nitrogen Metabolism. 1956; McElry and Glass (eds.) The Johns Hopkins Press.

Bhattacharya S, Zaman MK, Haldar PK. Antibacterial Activity of stem Bark and Root of Indian Zanthoxylumnitidum. Asian J Pharm Clin Res. 2009; 2(1): 30-34.

Bradford MM.A rapid and sensitive method for the quantitation of microgram quantities of protein utilizing the principal of protein dye binding. Anal Biochem. 1976; 72: 248-254.

Farnsworth NR. Biology and Phytochemical screening of plants. Pharm Sci. 1966; 55: 225-276.

Harborne JB. Phytochemical Methods, Chapman and Hall, London. New York, 1984; 5-6.

Hema R, Kumaravel S, Gomathi S, Sivasubramaniam C. Gas Chromatography-Mass Spectroscopic analysis of Lawsoniainermis leaves. New York Sci J. 2010; 3: 141-143.

Hussain A, Zaman MK, Ramteke AM. Antibacterial Activity of Trunk Bark of Alstoniascholaris. Asian J Pharm Clin Res. 2010; 3(4): 46-47.

Jain T, Sharma K. Assay of antibacterial activity of Polyalthialongifolia Benth and Hook. Leaf extracts. $J$ Cell and Tissue Res. 2009; 9(2): 1817-1820.

Larcher W. Physiol Plant Ecol. Springer-Verlag. Berlin. 1995; 506.

Mc-Cready RM, Gujjolz, Silviers V, Owers HS. Determination of starch and amylase in vegetables. Application to Peas. Anal Chem. 1950; 22: 1156.

Muthulakshmi A, Jothibai-Margret R, Mohan VR.GCMS Analysis of Bioactive Components of Feroniaelephantum Correa (Rutaceae). J Applied Pharm Sci. 2012; 2(2): 69-74. 
Otimenyin O, Sunday, Uguru MO, Ogbonna A. Antimicrobial and hypoglycemic effects of Momordicabalsamina.Linn. J Nat Products. 2008; 1: 03-09.

Rajendra Kumar CSV, Reddy BVD, Reddy AR. Proline protein interactions: Protection of structural and functional integrity of M4 lactate dehydrogenase. Biochem Biophy Res Comm. 1994; 201:957-963.

Rios JL, Reico MC. Medicinal plants and antimicrobial activity. J Ethnopharmacol. 2005; 100: 80-84.

Siefermann-Harms D. The light-harvesting and protective functions of carotenoid in photosynthetic membranes. Physiol Plant. 1987; 69: 561-568.

Singariya P, Kumar P, Mourya KK. Antimicrobial Activity of Fruit coat (Calyx) of Withania somnifera against some Multi Drug Resistant Microbes. Int J Biological Pharm Res. 2012c; 3(2): 252-258.

Singariya P, Kumar P, Mourya KK. Evaluation of Antibacterial Activity and Preliminary Phytochemical Studies on the Stem of Cenchrus ciliaris and Cenchrus setigerus. Asian J Pharm Clin Res. 2012b; 5(1): 163-167.

Singariya P, Kumar P, Mourya KK. Phyto-chemical Screening and Antimicrobial Activities of Dhaman grass and Indian Ginseng. J Pharmacy Res. 2012a; 5(1): 135-139.

Singariya P, Kumar P, Mourya KK. Ripen Fruits of Indian Ginseng: Phyto-chemical and Pharmacological examination against Human and Plant Pathogens. Int J Appl Biol Pharm Tech. 2012e; 3(2): 1-8.

Singariya P, Mourya KK, Kumar P. Antimicrobial Activity of the Crude Extracts of Withania somnifera and Cenchrus setigerusIn-vitro. Pharmacogn J. 2012d; 4(27): 60-65.
Singariya P, Mourya KK, Kumar P. Bio Activity of crude extracts of Leaves of Cenchrus Grass in different polar solvents against some pathogenic microbes. Int J Pharm Sci Review and Res. 2011b; 11(1): 124-129.

Singariya P, Mourya KK, Kumar P. Comparative Microcidal Activity of Withania somnifera and Cenchrus setigerus against the Pathogenic Microorganisms. Int J Pharmacy Pharm Sci. 2011c; 3(5): 511-555.

Singariya P, Mourya KK, Kumar P. Preliminary Phytoprofile and Pharmacological Evaluation of some Extracts of Cenchrus grass against Selected Pathogens. J Pharm Sci Res. 2011a; 3(8): 1387-1393.

Singariya P, Rathi P, Gadi BR, Bohra SP. Effect of Ethephon on the Activities of Ammonia Assimilation Enzymes and Metabolites of Cenchrus Setigerus-76 grown in vivo. Adv Microbiol Biotechnol. 2009; 347351.

Singariya P. Effect of Sub-Optimal Environment and PGR's on Metabolic Pattern of Certain Species of Cenchrus. Ph.D Thesis.J. N. Vyas University. 2009.

Singleton S, Rossi T. Methodology of plant metabolites and enzymes. Vol. II, (eds.), Bhansali R R, Jindal S K. 1995; 245-265.

Sinha RK, Bhatia S, Vishnoi R. Desertification control and rangeland management in the Thar desert of India. 1996; In: Rala Report no. 200, 115-123.

Vyvyan JR. Allelo-chemicals as leads for new herbicides and agrochemicals. Tetrahedron.2002; 58:1631-1646. 